\title{
The hyperpycnite problem: comment
}

\author{
A. J. (Tom) van Loon ${ }^{1,2^{*}}$ (D) Heiko Hüneke ${ }^{3}$ and Thierry Mulder ${ }^{4}$
}

\begin{abstract}
A recent review article ("The hyperpycnite problem") by Shanmugam (Journal of Palaeogeography 7(3):197-238, 2018) in this journal has some shortcomings, comes to scientifically incorrect conclusions, and calls for student education in a way that would significantly diminish the students' changes for a geological career. Having studied--and still studying--hyperpycnites in the field, it seems only appropriate to inform the readers of this journal about our concerns regarding the review article mentioned above.

Actually, the article by Shanmugam (Journal of Palaeogeography 7(3):197-238, 2018) is not a review paper but rather a comment, criticizing all researchers who have come to the conclusion, on the basis of both field research and theory, that hyperpycnal flows result in sediments (hyperpycnites) with characteristics that make it possible to distinguish them from deposits formed in another way. This is also the essence of Shanmugam's comment: as he states himself, he is "an ardent critic of all genetic facies models".
\end{abstract}

\section{General comment}

Obviously, Shanmugam (2018) mentions his main points of criticism in his abstract. Our comments will therefore follow the order of topics in his abstract, also in order to make this comment more reader-friendly. We will, however, also refer to the main text of Shanmugam where appropriate.

On request by the Editor-in-Chief, we will do so in a complex way, indicating page number, column, and line number. As an example," 225/1/17" will indicate a text in Shanmugam's paper on page 225, left column, line 17, neglecting headings, possible lines in captions of figures and tables, and also neglecting blank lines. Comments on texts in right-hand columns will be indicated as, for example, "225/r/17-20" indicating lines $17-20$ in the right-hand column of page 225. Where we refer to Shanmugam's (page-wide) abstract on page 197, the code ' $197 / x-y$ ' will be used, where ' $x-y$ ' indicate the line numbers below the heading.

\section{Shanmugam's views vs. commonly accepted views}

Shanmugam mentions (197/1-7) that some 'claims' from researchers who accept the hyperpycnite concept are

\footnotetext{
* Correspondence: Geocom.VanLoon@gmail.com; tom.van.loon@wxs.nl ${ }^{1}$ Geocom Consulting, Valle del Portet 17, 03726 Benitachell, Spain ${ }^{2}$ College of Earth Science and Engineering, Shandong University of Science and Technology, Qingdao 266590, Shandong, China

Full list of author information is available at the end of the article
}

"not supported by empirical data from modern depositional systems". He rejects the following four commonly accepted points of view: (1) transformation of flows, (2) erosional power of hyperpycnal flows, (3) sand transported by hyperpycnal flows across the shelf, and (4) existence of hyperpycnal flows in modern settings.

\subsection{Transformation of flows}

Shanmugam rejects claims that "river flows transform into turbidity currents at plunge points near the shoreline" (197/2-3). He details this in his sections 1.3 (199/1/5), $2.3(203 / \mathrm{r} / 1-7)$ and $2.7(205 / \mathrm{r} / 18-26)$ and summarizes his view in his section $3.10(210 / \mathrm{r} / 48-52)$. Our comment: unfortunately, Shanmugam does not indicate which authors claim this. We are not aware of any sedimentological study that does so. If it were true, no hyperpycnites but only turbidites would be found in deep basins, but numerous articles demonstrate the existence of deep-marine hyperpycnites as well (see Mulder 2011). For example, Nakajima (2006) described hyperpycnites in the Toyama deep-sea fan, at more than $700 \mathrm{~km}$ from the river mouth and from a water depth of more than $3000 \mathrm{~m}$.

Hyperpycnal flows are also important as a geological feature that represents events that occur relatively rarely, but that result in transport and depositions of sediments with sometimes huge volumes; they also may reflect extreme conditions. As an example, a decimeter-thick red silt bed has been described from cores collected in the 
central Hudson Bay and the western Hudson Strait. It shows reverse-to-normal grading, and was interpreted by Lajeunesse and Saint-Onge (2008) as a hyperpycnite related to the final outburst of the Lake AgassizOjibway. Deep-lacustrine hyperpycnites have been demonstrated as well. In modern clastic lakes, millimeter- to centimeter-thick hyperpycnites with a sharp base and with the characteristic grading couplets are present (Guyard et al. 2007). High-magnitude flood events frequently are characterized by graded silty deposits in proximal environments suggesting hyperpycnite-to-turbidite transformation, but they are characterized by very fine-grained (clayey silts) deposits with sharp bases when deposited in a deep distal basin (Chapron et al. 2007).

\subsection{Erosional power of hyperpycnal flows}

Shanmugam rejects also the commonly accepted view that "hyperpycnal flows have the power to erode the seafloor" (197/2-3). He comes back to this point in his section 1.3 (199/1/6-8), without, however, detailing this. Our comment: hyperpycnal flows exist not only in the marine realm, but also in lacustrine settings. As will be detailed in Section 5.2, clear proof exists that hyperpycnal flows can erode lacustrine bottom sediments; as sediment-gravity flows are not capable of distinguishing between similar soft-sediments accumulated in different environments, there is no reason why they would not be able to erode the soft sediments over which they are flowing in a marine basin.

\subsection{Sand transport by hyperpycnal flows}

Shanmugam does not agree that "hyperpycnal flows [...] can deliver sediments into the deep sea" (197/3-4). He works this out in his sections 1.3 (199/1/10-12), 2.2 (203/1/29-33), 2.7 (205/r/38-41), $7.3(221 / 1 / 8-11)$ and 9.2.1 (228/r/9-12). Our comment: we can only repeat that, if this were true, no deep-marine hyperpycnites would exist and the sequences described by Nakajima (2006) would not exist either.

Shanmugam consequently also disagrees with the view that "hyperpycnal flows are efficient in transporting sand across the shelf" (197/3-4), suggesting that all sands supplied by rivers into seas or lakes would be left behind near-shore or on deltas. He works this out in his sections 1.3 (3/l/11-13; 3/r/7-10), 2.2 (7/1/29-33; 7/r/810), 2.7 (7/r/38-41), 3.10 (14/48-51), 4.3 (16/r/5-8) and 7.3 (25/1/8-11), and provides additional data in his Fig. 3 and Table 1. Our comment: if gravity flows are not capable of transporting sand across the shelf, where do sandy deep-sea turbidites come from (according to Shanmugam himself, turbidity currents and hyperpycnal flows act in the same way; he even mentions a hyperpycnal turbidity current: e.g., 197/17-18, 202/1/20)?

\subsection{Practice vs. theory}

According to Shanmugam, claims that hyperpycnal flows can form deposits in the deep sea are "based strictly on experimental or theoretical basis, without the supporting empirical data from modern depositional systems" (197/6-7). He elaborates this in many places, particularly referring to laboratory experiments carried out by Lamb et al. (2010), for instance in sections $2.7(206 / 1 / 4-18)$ and $6.1(215 / 1 /$ 21-24). Our comment: The experiments mentioned by Shanmugam deal with a limited number of flows under restricted conditions that cannot be considered representative for nature, as has been detailed (Yang et al. 2019) in a reply to a comment by Shanmugam (2019) on an earlier contribution that was devoted to the results of field investigation of lacustrine hyperpycnites (Yang et al. 2017a).

The laboratory experiments referred to by Shanmugam had been conducted by Lamb et al. (2010), whose experiments simulating deep-sea hyperpycnal flows did not support the hyperpycnite theory. It should be kept in mind, however, that sea water has a higher density than the fresh water in lakes, so that hyperpycnal flows will originate much more easily in a lake than in the sea. Moreover, the experiments constituted "one of the first experimental flume studies" and can consequently not be considered as providing a final, decisive answer to the topic under investigation.

Further, Lamb et al. (2010) stated that "depth-averaged hyperpycnal-flume velocities can be uncorrelated or even anti-correlated with river discharge at certain seabed locations." Note the uncertainties: (a) how must depth-averaged velocity in flumes be compared with actual hyperpycnal-flow velocities? (b) how should the velocity of the (short-distance) flume plume be compared with actual velocities? (c) the experiments show that the results "can be" uncorrelated (or even anti-correlated) to river floods; how often can they be correlated, anticorrelated or not correlated (it is intriguing that Shanmugam does not wonder here about quantification!)? (d) the experimental results are valid for "certain seabed conditions": what conditions and where? and what are the results elsewhere? and in how far did the "certain conditions" resemble actual deep-sea conditions? With so many uncertainties, it is hard to justify invalidating the hyperpycnal-flow model on the basis of the 'negative' results of Lamb et al.'s (2010) experiments.

Further, as mentioned above and detailed in Section 5.2, any doubt about the existence of hyperpycnal flows is unjustified since a modern hyperpycnite has actually been visible for numerous people.

\section{Variations in conditions}

Shanmugam mentions (197/9-15) 6 different environments in which density plumes can be formed, 6 different materials of which they may be composed, 11 
sources from which the materials may be derived, 15 external controls to which density plumes can be exposed, and 24 configurations that density plumes may take. He devotes much text (only the two case studies of the Yellow River and the Yangtze River take not less than over six pages) and many figures to detail this, but neglects the actual observation of a hyperpycnal flow in a reservoir lake in the Yellow River. Moreover, numerous sedimentological studies have made clear that more environments with density plumes exist than mentioned by Shanmugam, that more types of material can be transported by hyperpycnal flows, and that more sources and configurations exist, so that the numbers provided by Shanmugam represent only an apparent accuracy.

Our most important comment is, however, that Shanmugam does in no way indicate what sources etc. have to do with his divergent view regarding the concept of hyperpycnal flows and their deposits, so that these text parts, in our opinion, are superfluous.

\section{Shanmugam's major problem areas}

Shanmugam mentions 10 aspects (197/16-34) that he considers to pose major problems, although he does not indicate for all these topics why they are problematic with respect to the concepts of hyperpycnal flows and hyperpycnites.

1) "There are at least 16 types of hyperpycnal flows" (197/16-18; see also his sections 2.5 and 3.3). Our comment: apart from the fact that he combines two fundamentally incomparable categories (densitydependent flows and flows with different trigger mechanisms), it remains unclear why the existence of different types would pose a problem regarding the fact that they are all sediment-gravity flows and that they can form deposits with their own sedimentary characteristics (as far as the flow types and/or conditions differ!).

2) "The basic tenet that river currents transform into turbidity currents [...] is based on experiments that used fresh tap water" (197/18-20), which would make them inapplicable to marine waters. Shanmugam elaborates on these experiments in his section 2.7, concluding that the "experimental results on hyperpycnal flows are applicable only to fresh-water lakes, but not to marine bodies of water (sea or ocean)" (206/1/9-12). Our comment: apart from the fact that sediment-laden river currents result commonly in hyperpycnal flows rather than in turbidity currents (e.g. Parsons et al. 2001; Mulder et al. 2003; Bourget et al. 2010; Talling 2014), this does not imply that hyperpycnal flows cannot form in a marine environment, because a high sediment load can make the inflowing river water denser than marine (saline) water. We refer the reader here also to our above Section 2.4, where we explain that the experiments that Shanmugam refers to cannot be considered as representative, and that the results of these experiments contain significant uncertainties.

3) "The presence of tidal shear front at the Yellow River mouth limits seaward transport of sediments" as is deduced by Shanmugam from "published velocity measurements" that "are of tidal currents, not of hyperpycnal flows" (197/21-23). In his long section about the Yellow River (206/r/13-211/l/2), Shanmugam comes to conclusions that make not truly clear whether he agrees with the occurrence of hyperpycnal flows in the area in front of the Yellow River mouth or not. Our comment: even if he denies the presence of discharge-induced hyperpycnal flows in this area, it should be realized that the absence of hyperpycnal flows at one specific place cannot be taken as an argument against the existence of such flows elsewhere.

4) The "hyperpycnite facies model has not been validated by laboratory experiments or by realworld empirical field data from modern settings" (197/23-24). Our comment: the first statement is contradictory with his own above statement (206/1/ 4-6) (see also point 2 of this section). The second statement is a repetition of his statement in the first paragraph, point (4), and it is clearly unjustified as we will show in Section 5.2. Moreover, experiments (see, for instance, Bowland and Hsu 2010) clearly show the formation of hyperpycnal flows. St-Onge et al. $(2003,2012)$ clearly related flood-induced successions to historical floods in the Saguenay Fjord. They clearly differentiate between true co-seismic Bouma-like turbidites and post-seismic erosion of co-seismic, slump-related natural dams by river snow melt floods. A magnificent, several-meter thick succession exhibits the stacked reverse-tonormal grading. Even more convincingly, splendid images of hyperpycnal-flow formation at the mouth of the Elwah River are shown on a USGS site (https://walrus.wr.usgs.gov/elwha/shorecoast.html); comparable pictures exist of the situation seawards of the Skeidararsandur (Iceland) after the Grimsvötn eruption in November 1996 (Fig. 3 in Mulder et al. 2003). Finally, Katz et al. (2015) published submarine pictures of a hyperpycnal flow formed during flashfloods in the Gulf of Aquaba (Israel). The video, which can be seen at https://www.youtube.com/watch?v=4r9ndJ80_1Y, was apparently not considered convincing by Shanmugam, as he does not refer to this video which is well known in the community of hyperpycnite researchers. 
5) "The presence of an erosional surface within a single hyperpycnite depositional unit is antithetical to the basic principles of stratigraphy" (197/25-26). Shanmugam illustrates his point of view in his Fig. 14 (p. 216). Our comment: Sedimentologists are, already for a long time, aware that each sedimentary succession is the net result of several processes that commonly include erosion and phases of non-deposition, as obvious from, for instance, each fluvial succession (Fielding 1993; Blum et al. 2009; Smith and Rogers 2009). Moreover, hyperpycnal flows, in contrast to other gravity flows, commonly last for weeks or even more, with consequently fluctuations in the sediment supply, and with erosional phases due to increasing energy during waxing of the flow (Wright et al. 1986; Mulder and Syvitski 1995; Mutti et al. 1996). In addition, it is now well-established that the basal erosional surface of a turbidity current is usually formed by some successive events that usually precede the one that deposits the $T_{a}-T_{e}$ units of the Bouma sequence, if complete (Peakall et al. 2018). It should be mentioned in this context that, since the very early days of turbidite research (Kuenen and Migliorini 1950), thousands of turbidites have been described with complete Bouma sequences (Bouma 1962), that never have been explained satisfactorily in another way, so that refusal of the turbidite concept and of Bouma sequences (see also Shanmugam 1997) cannot be taken as an argument against hyperpycnal flows.

6) "The hypothetical model of "extrabasinal turbidites", deposited by river-flood triggered hyperpycnal flows, is untenable" (197/26-27). Shanmugam works this view out in a section running from $220 / \mathrm{r} / 15$ to $221 /$ $1 / 5$. His main argument is that such a process and the resulting deposits have never been documented in the world's oceans. Our comment: the impact of large meteorites, Snowball (or Slushball) Earth, the evolution of life, and most processes that have severely affected the Earth have not been documented either; they are reconstructed on the basis of observations and interpretations. As long as a hypothesis is unproven, scientists should try to prove or falsify it, not just reject it. Moreover, strong arguments for extrabasinal turbidites/ hyperpycnites are given in studies referred to by Shanmugam himself (Zavala and Arcuri 2016; Zavala and Pan 2018).

7) "Although plant remains are considered a criterion for recognizing hyperpycnites ...." (197/28-29). In his section 6.7, Shanmugam states that Zavala and Arcuri (2016) consider plant remains as a criterion for the recognition of hyperpycnites. Our comment:
Although these authors mention, indeed, that plant remains are common in hyperpycnites (and they provide numerous examples), they do not state that their presence is a distinctive criterion. This is evident, as plant remains that are washed into a sea or a lake can float or otherwise be transported and eventually sink and be buried. Although they may be transported by hyperpycnal flows, their presence is therefore, in contrast to what Shanmugam states, not considered as a diagnostic criterion for hyperpycnal flows by any expert sedimentologist.

8) "Genuine hyperpycnal flows are feeble and muddy by nature, and they are confined to the inner shelf in modern settings" (197/30-31). This statement is, unfortunately, not worked out in the text. Our comment: It is not clear what Shanmugam means with "genuine" hyperpycnal flows. He uses this term only once more $(28 / \mathrm{r} / 20)$, but he does not explain this term there either. Moreover, Shanmugam himself mentions repeatedly that turbidity currents and hyperpycnal flows behave in very comparable ways. It is therefore only understandable that numerous studies indicate that hyperpycnites, like turbidites, occur far away from the shore in deep-water environments (Yang and Van Loon 2016; Yang et al. 2016, 2017b, 2018; Zhao et al. 2018). If turbidites can run over a hundred kilometers or more, and if-like Shanmugam states repeatedly-turbidity currents and hyperpycnal flows flow in the same way, why would hyperpycnal flows not run that far? Moreover, as we will show in Section 5.2, they do, as has been documented from a modern setting.

9) "Distinguishing criteria of ancient hyperpycnites from turbidites or contourites are muddled" (197/ 32). Shanmugam works this out in his section 6.4 (217/1/28-48) for contourites, but not for turbidites. He only mentions in his next section (6.5) about massive sandstones that "conventionally massive sand intervals are interpreted as the Bouma $\mathrm{Ta}$ division of a turbidite bed" (217/r/32-37), but this has little-if anything-to do with the distinction of hyperpycnites, as the latter are graded by definition. Our comment: Researchers involved for a long time in deep-sea research are all convinced that the micro-scale couplets of reversed and normal grading cannot be explained satisfactorily in another way (e.g. Bourget et al. 2010; Talling 2014). Unfortunately, Shanmugam does not offer an alternative explanation.

10) "After 65 years of research since Bates (AAPG Bulletin 37: 2119-2162, 1953), our understanding of hyperpycnal flows and their deposits is still incomplete and without clarity" (197/34-36). Our 
comment: Bates dealt with deltas, not with hyperpycnal flows, a feature that was still unknown at the time. Of course, our understanding is still incomplete, like it is for all other types of geological processes. It is not true, however, that there is no clarity: Shanmugam sees problems where more expert researchers see the light (see, for instance, Mulder and Alexander 2001; Mulder 2011; Mulder and Hüneke 2016).

\section{Some additional comments}

The 42 pages of Shanmugam's (2018) review contain, understandably, more questionable points than mentioned above. It seems out of scope to deal with all of them here, however, as this would require a much lengthier comment. Consequently, we want to make clear here only that there are some more aspects that give the readers an incorrect impression of the state-of-the-art regarding our knowledge of hyperpycnites, and that therefore deserve attention here.

\subsection{Turbidity currents vs. hyperpycnal flows}

The entire review of Shanmugam is self-contradictory where turbidity currents and hyperpycnal flows are concerned. On the one hand, Shanmugam states that at least the transport mechanism of both types of flow is the same, but on the other hand he mentions over and over again the existence of both types of flow, even suggesting that one type can transform into the other type. If both types are the same, how can they transform into one another? And why do their deposits differ in so many aspects? On the other hand, if both types are different, why doesn't Shanmugam admit that their deposits reflect these differences?

\subsection{A modern hyperpycnal flow}

The most convincing argument against Shanmugam's statement that hyperpycnal flows never have been observed in modern settings is a feature that occurred in China: a hyperpycnal flow that ran through the Xiaolangdi Reservoir Lake for $>100 \mathrm{~km}$ (Yang et al. 2015), when a disastrous flood of the Yellow River entered the reservoir. Shanmugam devotes over five pages to the Yellow River but, remarkably enough, does not even mention this feature. The density flow running over the bottom of the lake became visible when an exceptionally high river discharge lasted so long that the reservoir lake threatened to overflow. In order to release water from the lake, gates were opened at both the bottom and the top of the dam. The hyperpycnal flow, which had eroded sediment from the reservoir's lake bottom, flowed out through the gates in the dam near the bottom, so that a brown sediment-laden, high-density water mass was released. In contrast, the water that was released through the upper openings in the dam, and which had not yet mixed with the hyperpycnal flow, showed a bright white color (Fig. 1). This is direct proof of the existence of a modern hyperpycnal flow, and is mentioned in the literature.

Further proof comes from Crookshanks and Gilbert (2008), who used combined in situ measurements such as particle trap, acoustic profiles along the water column and sampling at the water/sediment interface of a lake

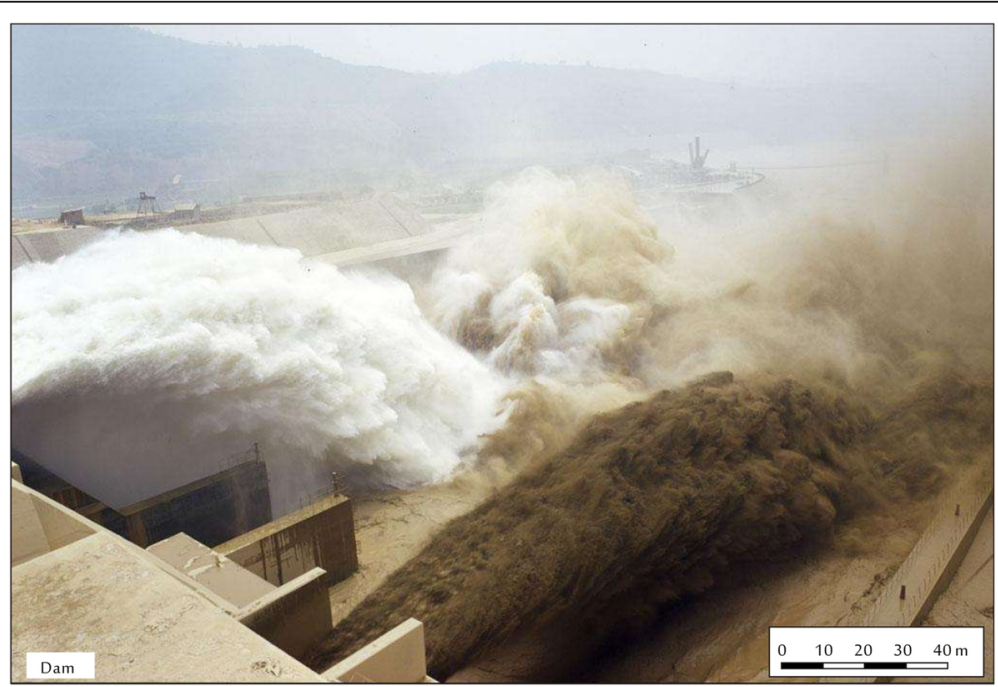

Fig. 1 Gates near both the top and the bottom of the reservoir dam of the Xiaoliandi Reservoir Lake were opened when a disastrous flood of the Yellow River threatened to overflow the dam. Huge water masses could thus be released. The water released from the top part of the lake, flowing through the upper gates of the dam, was clean. Due to mixing with air, this water was bright white. In contrast, the water released through the gates near the bottom had a brown color. This water was sediment-laden because a long-lived hyperpycnal flow eroded and whirled up much sediment from the reservoir's bottom. (From Yang et al. 2018, after https://www.quanjing.com/imgbuy/QJ8103941831.html) 
to demonstrate the emplacement of a hyperpycnite in Kluane Lake (Canada), linking the flow velocity to the classical double-grading hyperpycnite.

Finally, we refer to our Section 4, point 4, where we already mentioned splendid images of a hyperpycnal-flow at the mouth of the Elwah River, and to a video published by Katz et al. (2015) showing a submarine hyperpycnal flow. With so much proof of actual occurrences of hyperpycnal flows in modern settings, it is not well understandable that their existence can still be denied.

\section{Conclusions}

The review article by Shanmugam is based on insufficient insight into the sedimentology of hyperpycnal flows. This must be ascribed to the fact that he did not study the resulting sediments himself (his 42-page article contains only one single photo of a sediment, and this photo was taken, without our permission, from a paper that one of us co-authored: Yang et al. 2017a), but bases his arguments mainly on satellite images and maps that are derived from such images (over 30 figures). Using satellite images can be very helpful in the earth sciences, indeed, but it is not the right tool to study subaqueous transport processes and the resulting deposits. Sedimentology can proceed only if the sediments themselves are taken as the prime source of information, and if the various erosional, transport and depositional processes are studied in the field, wherever possible. This has led in the past to a giant step forwards in the form of genetic models; the advice given by Shanmugam to students that they should not use such models is an equally giant step backwards.

Although hyperpycnites and their genesis now are a hot topic (partly because they increase our insight into the morphological development of the continental slope, as well as into the occurrence of allochthonous sediments in distal, deep-water environments), the community of hyperpycnite researchers is still relatively small. This enables good and effective communication. In this context it is understandable that we have been informed by several colleagues that they, too, have submitted comments on the hyperpycnite paper by Shanmugam. Therefore, we will not go further into detail here with our comments. We hope that the sedimentological and marine-geological communities will profit from the academic discussion that is initiated by Shanmugam's (2018) views.

\section{Acknowledgements}

The authors acknowledge the help of colleagues, editors and reviewers who commented on an earlier version of the manuscript.

\section{Availability of data and materials}

The comment is based on the paper by Shanmugam referred to, on literature search, and on own data presented in publications, the most relevant of which are referred to.

\section{Authors' contributions}

AJVL initiated the comment, wrote a first concept and coordinated the work. $\mathrm{HH}$ and TM carried out literature search and added additional data. All authors read and approved the final manuscript.

\section{Competing interests}

The authors declare that they have no competing interests.

\section{Publisher's Note}

Springer Nature remains neutral with regard to jurisdictional claims in published maps and institutional affiliations.

\section{Author details}

${ }^{1}$ Geocom Consulting, Valle del Portet 17, 03726 Benitachell, Spain. ${ }^{2}$ College of Earth Science and Engineering, Shandong University of Science and Technology, Qingdao 266590, Shandong, China. Institute of Geography and Geology, Greifswald University, Greifswald, Germany. ${ }^{4}$ UMR CNRS EPOC, University of Bordeaux, Allée Geoffroy St-Hilaire, 33615 Pessac Cedex, France.

Received: 28 September 2018 Accepted: 2 April 2019

Published online: 13 June 2019

\section{References}

Blum, M.D., Marriott, S.B., and Leclair, S.F. (Eds.) 2009. Fluvial Sedimentology VII. Wiley online library: ISBN 9781444304350.

Bouma, A.H. 1962. Sedimentology of some flysch deposits--A graphic approach to facies interpretation, 168. Amsterdam: Elsevier.

Bourget, J., S. Zaragosi, T. Mulder, J.-L. Schneider, T. Garlan, A. Van Toer, V. Mas, and N. Ellouz-Zimmermann. 2010. Hyperpycnal-fed turbidite lobe architecture and recent sedimentary processes: A case study from the Al Batha turbidite system, Oman margin. Sedimentary Geology 229: 144-159.

Bowland, T.M., and Hsu, T. 2010. An experimental investigation of hyperpycnal flow. American Geophysical Union, Fall Meeting 2010, Abstract, OS51B-1283.

Chapron, E., E. Juvigné, J. Mulsow, D. Ariztegui, O. Magand, S. Bertrand, M. Pino, and O. Chapron. 2007. Recent clastic sedimentation processes in Lake Puyehue (Chilean Lake District, $40.5^{\circ} \mathrm{S}$ ). Sedimentary Geology 201: 365-385.

Crookshanks, S., and R. Gilbert. 2008. Continuous, diurnally fluctuating turbidity currents in Kluane Lake, Yukon territory. Canadian Journal of Earth Sciences 45: 1123-1138.

Fielding, C.R. 1993. A review of recent research in fluvial sedimentology. Sedimentary Geology 85: 3-14.

Guyard, H., G. St Onge, E. Chapron, F. Anselmetti, and P. Francus. 2007. The AD 1881 earthquake-triggered slump and late Holocene flood-induced turbidites from proglacial lake Bramant, western French Alps. In Submarine mass movements and their consequences, ed. V.D. Lykousis, D. Sakellariou, and J. Locat, 279-286. Dordrecht: Springer.

Katz, T., H.Z. Ginat, G. Eyal, Z. Steiner, Y. Braun, S. Shalev, and B.N. Goodman-Tchernov. 2015. Desert flash floods form hyperpycnal flows in the coral-rich Gulf of Aqaba, Red Sea. Earth and Planetary Science Letters 417: 87-98.

Kuenen, Ph.H., and C.I. Migliorini. 1950. Turbidity currents as a cause of graded bedding. The Journal of Geology 58: 91-127.

Lajeunesse, P., and G. Saint-Onge. 2008. The subglacial origin of the Lake Agassiz-Ojibway final outburst flood. Nature Geoscience 1: 184-188.

Lamb, M.P., B. McElroy, B. Kopriva, J. Shaw, and D. Mohrig. 2010. Linking river-flood dynamics to hyperpycnal-plume deposits: Experiments, theory, and geological implications. GSA Bulletin 122: 1389-1400.

Mulder, T. 2011. Gravity processes on continental slope, rise and abyssal plains. In Deep-Sea Sediments, Developments in Sedimentology 63, ed. H. Hüneke and T. Mulder, 25-148. Amsterdam: Elsevier. 
Mulder, T., and J. Alexander. 2001. The physical character of sedimentary density currents and their deposits. Sedimentology 48: 269-299.

Mulder, T., and H. Hüneke. 2016. Turbidite. In Encyclopaedia of marine geosciences, ed. J. Harff, M. Meschede, S. Petersen, and J. Thiede, 888892. Dordrecht: Springer.

Mulder, T., and J.P.M. Syvitski. 1995. Turbidity currents generated at river mouths during exceptional discharges to the world oceans. The Journal of Geology 103: 285-299.

Mulder, T., J.P.M. Syvitski, S. Migeon, J.-C. Faugères, and B. Savoye. 2003. Marine hyperpycnal flows: Initiation, behavior and related deposits. A review. Marine and Petroleum Geology 20: 861-882.

Mutti, E., G. Davoli, R. Tinterri, and C. Zavala. 1996. The importance of ancient fluviodeltaic systems dominated by catastrophic flooding in tectonically active basins. Memorie di Scienze Geologiche 48: 233-291.

Nakajima, T. 2006. Hyperpycnites deposited $700 \mathrm{~km}$ away from river mouths in the Central Japan Sea. Journal of Sedimentary Research 76: 60-73.

Parsons, J.D., J.W.M. Bush, and J.P.M. Syvitski. 2001. Hyperpycnal plume formation from riverine outflows with small sediments concentrations. Sedimentology 48: 465-478.

Peakall, J., Best, J., Baas, J., Hodgson, D., Clare, M., Talling, P., and Dorrell, R. 2018. An integrated process-based model of flute and tools in deepmarine systems. 20 $0^{\text {th }}$ ISC (August 13-17 th , Quebec City, Canada) Abstract, MO-4.2-C3-0.

Shanmugam, G. 1997. The Bouma sequence and the turbidite mind set. Earth-Science Reviews 42: 201-229.

Shanmugam, G. 2018. The hyperpycnite problem. Journal of Palaeogeography 7 (3): 197-238.

Shanmugam, G. 2019. Climatic and tectonic controls of lacustrine hyperpycnite origination in the Late Triassic Ordos Basin, central China: Implications for unconventional petroleum development: comment. AAPG Bulletin (in press).

Smith, N.D., and Rogers, E. (Eds.). 2009. Fluvial Sedimentology VI. Wiley online library: ISBN 9781444304213.

St-Onge, G., E. Chapron, S. Mulsow, M. Salas, M. Viel, M. Debret, A. Foucher, T. Mulder, M. Desmet, P. Costa, B. Ghaleb, A. Jaouen, and J. Locat. 2012. Comparison of earthquake-triggered turbidites from the Saguenay (eastern Canada) and Reloncavi (Chilean margin) fjords: Implications for paleoseismicity and sedimentology. Sedimentary Geology 243/244: 89-107.

St-Onge, G., T. Mulder, D.J.W. Piper, C. Hillaire-Marcel, and J. Stoner. 2003. Earthquake and flood-induced turbidites in the Saguenay Fjord (Québec): A Holocene paleoseismicity record. Quaternary Science Reviews 23: 283-294.

Talling, P. 2014. On the triggers, resulting flow types and frequencies of subaqueous sediment density flows in different settings. Marine Geology 352: 155-182

Wright, L.D., Z.-S. Yang, B.D. Bornhold, G.H. Keller, D.B. Prior, and W.J. Wisenam Jr. 1986. Hyperpycnal flows and flow fronts over the Huanghe (Yellow River) delta front. Geo-Marine Letters 6: 97-105.

Yang, R., A. Fan, Z. Han, and A.J. Van Loon. 2016. An upward shallowing succession of gravity flow deposits in the early cretaceous Lingshandao formation, western Yellow Sea. Acta Geologica Sinica 90: 1553-1554.

Yang, R., A. Fan, A.J. Van Loon, Z. Han, and C. Zavala. 2018. The influence of hyperpycnal flows on the salinity of deep-marine environments, and implications for the interpretation of marine facies. Marine and Petroleum Geology 98: 1-11.

Yang, R., Z. Jin, D. Sun, and A. Fan. 2015. Discovery of hyperpycnal flow deposits in the late Triassic lacustrine Ordos Basin. Acta Sedimentologica Sinica 33: 10-20 (in Chinese with English abstract).

Yang, R., Z. Jin, A.J. Van Loon, Z. Han, and A. Fan. 2017b. Climatic and tectonic controls of lacustrine hyperpycnite origination in the late Triassic Ordos Basin, Central China: Implications for unconventional petroleum development. AAPG Bulletin 101: 95-117.

Yang, R., Z. Jin, A.J. Van Loon, Z. Han, and A. Fan. 2019. Climatic and tectonic controls of lacustrine hyperpycnite origination in the late Triassic Ordos Basin, Central China: Implications for unconventional petroleum development: Reply. AAPG Bulletin (in press).
Yang, R.C., A.P. Fan, Z.Z. Han, and A.J. Van Loon. 2017a. A marine or continental nature of the deltas in the early cretaceous Lingshandao formation - evidences from trace elements. Acta Geologica Sinica 91: 367-368.

Yang, R.C., and A.J. Van Loon. 2016. Early cretaceous slumps and turbidites with peculiar soft-sediment deformation structures on Lingshan Island (Qingdao, China) indicating a tensional tectonic regime. Journal of Asian Earth Sciences 129: 206-219.

Zavala, C., and M. Arcuri. 2016. Intrabasinal and extrabasinal turbidites: Origin and distinctive characteristics. Sedimentary Geology 337: 36-54.

Zavala, C., and S.X. Pan. 2018. Hyperpycnal flows and hyperpycnites: Origin and distinctive characteristics. Lithologic Reservoirs 30: 1-27.

Zhao, L., Y. Zhou, and A.J. Van Loon. 2018. Soft-sediment deformation structures induced by rapid sedimentation in early cretaceous turbidites, Lingshan Island, eastern China. Canadian Journal of Earth Sciences 55: 118-129.

\section{Submit your manuscript to a SpringerOpen ${ }^{\circ}$ journal and benefit from:}

- Convenient online submission

- Rigorous peer review

- Open access: articles freely available online

- High visibility within the field

- Retaining the copyright to your article

Submit your next manuscript at $\boldsymbol{\nabla}$ springeropen.com 